\title{
The New Fear of One Another
}

\author{
Alphonso Lingis
}

Received: 23 June 2020 / Accepted: 17 August 2020

(C) Journal of Bioethical Inquiry Pty Ltd. 2020

\begin{abstract}
The COVID-19 contagion makes us fear anyone and everyone. Fear those with whom we are quarantined. Fear those confined in institutions. Doctors and nurses, who nonetheless care for us, know the most intense fear.
\end{abstract}

Keywords Fear $\cdot$ Nursing homes $\cdot$ African-and Hispanic Americans $\cdot$ False negatives $\cdot$ Caregivers

We now no longer look at others identified by their power, status, wealth, talents, skills, culture, or gender; we first see organisms like ourselves vulnerable to the deadly virus. We cannot fear for ourselves without fearing for them. What may strike people on the other side of the planet may strike me; what may save or heal them may save or heal me. To fear for oneself is also to fear for the others; to care for oneself is also to care for the others.

The fear isolates, throws one back upon oneself. We fear the others. Infected people are contagious in the days before symptoms of COVID-19 appear and also if no symptoms appear. Some 40 per cent of people who test positive for the virus are asymptomatic (Centers for Disease Control and Prevention 2020). Children are to be feared; when infected they typically show no symptoms and they do not keep social distance. As of this

\footnotetext{
A. Lingis $(\square)$

Pennsylvania State University, Lutherville, MD, USA

e-mail: allingis@hotmail.com
}

writing the current tests are thought to give false negative results 30 to 50 per cent of the time (Zhang 2020). The agency of our death lurks in any of the others. We see the Grim Reaper in anyone and everyone.

Though we show no symptoms we may be infected, may be shedding the virus. By putting food on the table we may be infecting our children, by taking the stairs or the elevator we may become a killer of strangers.

We have long lived in fear of the impoverished and oppressed. Afraid to walk alone among them, we have feared the force of their humiliation and desperation. Now we fear their bodies. In the United States African- and Hispanic-American people are dying of COVID-19 at about twice the rate of white people (APM Research Lab Staff 2020). Many African- and Hispanic-Americans have no health insurance or inadequate health insurance and often inadequately treated medical conditions. Many live in crowded housing and are working at essential services and have to take public transportation.

Forty-two million Americans receive food stamps in the Supplemental Nutrition Assistance Program, first established in 1939. In most states these people are not allowed to shop for groceries online; they must present themselves and their documents in person in grocery stores. People with incapacitating disabilities, destitute aged, children of destitute households, they are at high risk of infection by the virus and of shedding virus upon others.

Our societies confine criminals, refugees, the insane, the gravely handicapped, those prostrate in old age. They are at risk of all being stricken with the coronavirus from anyone among them. In nursing homes the residents have 
underlying medical conditions and are of the most highrisk age. Forty-two percent of all COVID-19 deaths are occurring in nursing homes (The New York Times 2020). Their guards and their caretakers connect them to us. They may be infected by us and we by them. We shun the homeless and the drug-addicted, but we are touching things they touch.

Sheltered at home, we fear those with whom we are quarantined. The state and nation-wide lockdowns have resulted in increased domestic violence and child abuse. Alcoholics and drug-addicts are suffering depression, bouts of aggression, and suicidal impulses. Gun violence and accidental firearm deaths of children are increasing.

Across the United States guns and ammunition sales have increased 85 per cent. In many states where all nonessential businesses were closed by governors' order, gun stores were decreed essential businesses. On March 28 the Trump administration included gun and ammunition manufacturers and importers, gun stores, and shooting ranges in the essential critical infrastructure workforce who are allowed to open during lockdowns.

Each of us urgently needs the others whom we fear.

Sixty million Americans are not self-quarantined, those in essential work, government officials, firefighters, police, workers maintaining the power grids, plumbers and electricians, workers in pharmacies, banks, and gas stations, truckers and bus drivers, workers in food production and distribution. A large number of people are required to deliver medical needs and groceries to people self-quarantined. All these workers are daily exposed to the risk of infection. For them to care for us they have to care for themselves. In caring for us they put themselves and consequently us at risk.

Doctors, nurses, paramedics, ambulance drivers, hospital kitchen and cleaning staff daily put themselves in proximity to those most sick and most contagious. In the United States 30.2 per cent of licenced doctors are sixty and older. Many retired doctors and nurses are returning to work as hospitals that are overwhelmed with afflicted patients. These doctors and nurses are most at risk; 80 percent of those who died from COVID-19 in China and in the United States have been of people sixty or older. As of this writing, in the United States a great many work without adequate personnel protective equipment, without suitable masks, gloves, gowns. Many do not have access to testing for themselves; they cannot know if while they have no symptoms they are contagious. They live in the fear of bringing the infection to their own families when they return home at the end of their shifts. Many of them sleep in trailers or vans or hotel rooms so as not to put their spouses and children at risk.

These people know fear, know it more deeply than we do. They are at high risk of being exposed, and they have seen just how they will die if they fall to the virus. They are not sacrificing themselves; they are desperately protecting themselves to stay alive. But they are working to protect, to heal, and to alleviate the dying of others. When the Ebola crisis emerged in West Africa, 35-year-old nurse Martha Phillips was eager to sign up. "It wasn't even necessarily a conscious decision," she says. "It was almost this frenetic drive of ... 'I can do this work, send me, I can help"' (Stone 2020). In the heart of a fear more immediate than the fear we know, they have to strength to do their work. It is because of them that the virus can be halted and the devastation of humanity be halted.

We fear for them and we understand them. This understanding shows that there is something of their motivation and their strength in us.

\section{References}

APM Research Lab Staff. 2020. The color of coronavirus: COVID-19 deaths by race and ethnicity in the U.S. APM Research Lab, August 5. https://www.apmresearchlab. org/covid/deaths-by-race. Accessed August 12, 2020.

Centers for Disease Control and Prevention. 2020. Pandemic planning scenarios. July 10. https://www.cdc. gov/coronavirus/2019-ncov/hcp/planning-scenarios.html. Accessed August 12, 2020.

Stone, W. 2020. Coronavirus nurses ask an Ebola veteran: Is it OK to be afraid? Kaiser Health News, April 16. https://khn. $\mathrm{org} /$ news/coronavirus-nurses-ask-an-ebola-veteran-is-it-okto-be-afraid/. Accessed August 12, 2020.

The New York Times. 2020. More than $40 \%$ of U.S. coronavirus death are linked to nursing homes. The New York Times, July 30. https://www.nytimes.com/interactive/2020 /us/coronavirus-nursing-homes.html. Accessed August 12, 2020.

Zhang, S. 2020. What a negative COVID-19 test really means. The Atlantic, June 21. https://www.theatlantic. com/science/archive/2020/06/how-negative-covid-19-testcan-mislead/613246/.Accessed August 12, 2020.

Publisher's note Springer Nature remains neutral with regard to jurisdictional claims in published maps and institutional affiliations. 